\title{
A Comparison between Experienced and Novice Teachers in Using Incidental Focus on Form Techniques in EFL Classrooms
}

\author{
Yassamin Pouriran (Corresponding author) \\ Tabriz Azad University, Iran \\ E-mail: yassaminp@gmail.com
}

Jayakaran Mukundan

Department of Languages and Humanities Education

Faculty of Education, Universiti Putra Malaysia, 43300 UPM Serdang, Selangor, Malaysia

E-mail: jaya@educ.upm.edu.my

Received: 01-09- 2012

Accepted: 02-10- 2012

Published: 01-11- 2012

doi:10.7575/ijalel.v.1n.6p.288

URL: http://dx.doi.org/10.7575/ijalel.v.1n.6p.288

\begin{abstract}
This paper reports the findings of an empirical study that explored whether EFL teachers' use of incidental focus-on-form techniques was influenced by their level of experience. Also, it investigated the distribution of incidental focus on form types at intermediate level and they were coded based on Lyster and Ranta (1997) and Panova and Lyster (2002) models. Incidental focus on form occurs spontaneously, without prior intention during meaning-focused activities and targets a variety of linguistic items. Here specific forms are not intentionally focused on, but are attended to spontaneously by teachers and other learners within meaning-driven contexts. Six teachers (three experienced and three novice) participated in this study. The data was drawn from transcripts of oral corrective feedback moves of six intact classes which were audio and video-recorded totaling 9 hours. A descriptive design which employed qualitative and quantitative data collection procedure was adopted. The results revealed that experienced teachers used incidental focus on form techniques more frequently than novice teachers. This study supports the notion that integrative activities which can integrate a focus on form into L2 communicative activities can contribute to learning a foreign language in terms of both accuracy and fluency.
\end{abstract}

Keywords: Corrective feedback- Incidental focus on form- Teacher experience

\section{Introduction}

As the focus of classroom instruction has shifted over the past few decades from an emphasis on language forms to functional language within communicative context, the question of error correction has become more and more important (Brown, 2004). Askew and Lodge (2000) state that the relationship between teaching and learning should be considered a dynamic process, rather than a one-way transmission of knowledge. Most of the interaction that takes place during EFL classrooms is guided by teachers, and thus they have a significant role in how students learn and what happens in the classroom. Furthermore, if it is true that students can learn from their own errors, then correcting those errors is a crucial part of learning. Accordingly, it is important to improve teachers' knowledge of their own actions, and thus teachers should be aware of the corrective feedback techniques they can apply in their classes.

In form- focused instruction there are some attempts to draw learners' attention to linguistic form while meaning-focused instruction requires learners to attend to the context or what they want to communicate (Ellis, 2001). Focus on form enables learners to take time out from a focus on meaning and notice linguistic items in the input, thereby overcoming a potential obstacle of purely meaning- focused lessons in which linguistic forms may go unnoticed (Loewen, 2003).

This research explored how EFL teachers with different levels of experience used incidental focus-on-form techniques in meaning based classes. Incidental focus on form is important pedagogically because it may facilitate the integration of attention to form and meaning (Long and Robinson, 1998) and because it may 
encourage learners to notice linguistic forms (Schmidt, 2001). The term form has often been used to refer to grammar, but this is not really what is meant by form. As Ellis et al. (2001a) argue, focus on form can be directed at phonology, vocabulary, grammar, discourse, and even spelling. Long (1991) offers the following definition of focus on form: "Focus on form ... overtly drawing students' attention to linguistic elements as they arise incidentally in lessons whose overriding focus is on meaning or communication" (pp. 45-46).

Based on the above definition, it could be argued that focus on form encourages learners to pay conscious attention to certain forms in the input, which they are likely to ignore. Such attention, according to Schmidt (1990), is necessary for acquisition to take place. Therefore, focus on form can be thought of as a useful device which facilitates the process of interlanguage development. Because of its widespread appeal, the term focus on form has been stretched beyond Long's original definition quoted above. Ellis (2001) conceptualizes form-focused instruction as "any planned or incidental activity that is intended to induce language learners to pay attention to linguistic form" (Ellis, 2001, pp.1-2). Ellis divided the general category of form-focused instruction into three approaches, which are summarized in Table 1. The first type of form-focused instruction is focus on forms. According to Long (1991), focus on forms is nothing but the traditional structural syllabus in which linguistic forms are isolated in order to be taught and tested one at a time. The second type of form-focused instruction is planned focus on form. Planned focus on form involves the use of communicative tasks designed to elicit preselected forms in a meaning-cantered context. The third type of form-focused instruction is incidental focus on form. In incidental focus on form, attention is given to linguistic problems as they arise spontaneously in the course of instruction and have not been explicitly chosen for teaching. Particularly, it involves the use of unfocused communicative tasks designed to elicit general samples of the language rather than specific forms (Ellis, Basturkmen, and Loewen, 2002).

Ellis et al. (2001b) define a Focus on Form Episode (FFE) as the unit of analysis in incidental focus on form studies. Each FFE includes "the discourse from the point where the attention to linguistic form starts to the point where it ends, due to a change in topic back to message or sometimes another focus on form" (Ellis et al., 2001b, p. 294).

The current study follows the model provided by Ellis (2001), who conceptualized form-focused instruction as "any planned or incidental instructional activity that is intended to induce language learners to pay attention to linguistic form" (pp. 1-2). In other words, Ellis included instructional activities that are associated with traditional grammar teaching following a synthetic syllabus, activities that Long $(1991 ; 2000)$ defined as focus on forms.

Table 1. Types of Form-focused Instruction (Source: Ellis, 2001, p. 17)

\begin{tabular}{|l|l|l|l|}
\hline $\begin{array}{l}\text { Type of } \\
\text { form-focused } \\
\text { instruction }\end{array}$ & $\begin{array}{l}\text { Primary focus of } \\
\text { attention }\end{array}$ & $\begin{array}{l}\text { Distribution of } \\
\text { attention to form }\end{array}$ & Examples \\
\hline Focus on forms & Form & Intensive & $\begin{array}{l}\text { Explicit and implicit grammar instruction, } \\
\text { functional language practice }\end{array}$ \\
\hline $\begin{array}{l}\text { Planned focus of } \\
\text { form }\end{array}$ & Meaning & Intensive & $\begin{array}{l}\text { Input flood, input enhancement, focused } \\
\text { communicative tasks }\end{array}$ \\
\hline $\begin{array}{l}\text { Incidental focus on } \\
\text { form }\end{array}$ & Meaning & Extensive & $\begin{array}{l}\text { Explicit and implicit negative feedback, } \\
\text { preemptive language focus }\end{array}$ \\
\hline
\end{tabular}

Within the category of incidental focus on form, Ellis further distinguished between pre-emptive and reactive techniques.

\subsection{Pre-emptive focus on form}

In pre-emptive incidental focus on form, the teacher draws the learner's attention to a form before a problem arises. The teacher briefly treats language as an object and may or may not use metalinguistic terminology. Ellis et al. (2001a) distinguish between teacher-initiated focus on form in which the teacher asks questions or gives information about particular linguistic items and student-initiated focus on form in which students raise questions about linguistic items. In teacher-initiated pre-emptive focus on form teachers interrupt the flow of a 
International Journal of Applied Linguistics \& English Literature

ISSN 2200-3592 (Print), ISSN 2200-3452 (Online)

Vol. 1 No. 6; November 2012

communicative activity to draw students' attention to a particular form. They do this because they consider it acceptable on the ground that the form in question may be problematic to some students.

\subsection{Reactive focus of form}

In reactive incidental focus on form, the teacher perceives the learner's utterance as inaccurate or inappropriate and draws her attention to the problematic feature through negative feedback. Reactive focus-on-form consists of the negative feedback which teachers provide in response to learners' errors. Negative feedback shows learners that an utterance they have just made is incorrect. This feedback occurs most often in conjunction with production practice. However, negative feedback seems to be more effective when used in activities in which the primary focus is on meaning rather than on form. Using the framework by Lyster and Ranta (1997) and Panova and Lyster (2002), teachers' feedback moves were coded into seven categories in the current study. The following explains each feedback type, along with examples from the actual data collected in the present study.

1. Explicit correction (i.e., the teacher supplies the correct form and clearly indicates that what the student said was incorrect). Example:

S: I am agree with my friend. (Grammatical error)

T: You agree with your friend, no need to say "am". (Explicit feedback)

S: I agree with her.

2. Recasts (i.e., the teacher implicitly reformulates all or part of the student's utterance, minus the error).

Example:

S: I was in a live [li:v] concert last month. (Phonological error)

T: A live [laIv] concert. (Recast)

S: oh, yes. A live concert.

3. Clarification requests (i.e., the teacher indicates to students that their utterance has been misunderstood by the teacher and a repetition or reformulation is needed). Example:

$\mathrm{S}$ : If we can find the major, we can complain about the problem. (Lexical error)

T: What? (Clarification feedback)

S: Oh... I mean manager not major.

4. Metalinguistic feedback (i.e., the teacher provides comments or questions related to the well formedness of the student's utterance). Example:

S: Service agent compensates to the damage. (Grammatical error)

T: You cannot use "to", you should use another preposition. (Metalinguistic feedback)

$\mathrm{S}$ : Yes, service agent compensates for the damage.

5. Elicitation (i.e., the teacher directly elicits a reformulation from the students). Example:

S: My brother had hurted his leg. (Grammatical error)

T: He had ..... (Elicitation feedback)

S: Sorry!... had hurt his leg.

6. Repetition (i.e., the teacher repeats the student's ill-formed utterance, adjusting intonation to highlight the error). Example:

S: And I was wrotting another sentence about schooling system. (Grammatical error)

T: I was wrotting... (Repetition)

S: No, no!.... I was writing another sentence about schooling system.

\section{Translation}

According to Panova and Lyster (2002) translations occur, when a teacher hears a student uses his/her L1 (first language), and if the use of L1 is not permitted, the teacher will translate the student's utterance from L1 to the target language. Example:

S: As a good friend, we must be "roorast" [in L1] (Lexical error) 
T: Honest. (Translation)

S: Oh... We must be honest.

\section{Literature Review}

Corrective feedback has recently attracted many researchers in SLA. Reactive focus on form has also been known as error correction, corrective feedback, or negative evidence/feedback (Long, 1996). On theoretical ground there are different views on the role of corrective feedback in SLA. Krashen $(1982,1985)$ is one of those researchers who believe that corrective feedback is not only useless but also harmful because it disrupts the flow of discourse. On the other hand there are many studies that show the effectiveness of corrective feedback. Schmidt (1990), Swain (1998), and Long (1996) are among those researchers who consider a facilitative role to corrective feedback. They argue that corrective feedback draws learners' attention to form, and this noticing to form helps them to recognize the gap between their interlanguage and target language. Ellis (2009) suggests that corrective feedback in the form of negotiating for meaning can help learners notice their errors and create form-meaning connections, and this facilitates acquisition.

\subsection{Incidental focus on form in L2 classrooms}

Incidental focus on form is important pedagogically because it creates opportunities for learners to attend to linguistic elements in a meaningful context as they arise incidentally within a broader framework of communication or meaning (Long, 2000; Long and Robinson, 1998). When learners experience problems with comprehension or production, they may experience a shift in attention from meaning to form. This shift in attention may promote noticing of linguistic forms, which Schmidt (2001) has argued is necessary for learning to occur. In addition, it may create opportunities for learners to notice gaps or holes in their target language knowledge, thereby leading them to search for the needed forms in the subsequent input (Swain, 1998).

Several studies have argued, using both theoretical and empirical support, for the benefits of specific types of reactive focus on form, such as recasts (e.g., Leeman, 2003; Han, 2002; Mackey and Philp, 1998), negotiation (e.g., Pica, 1994; Mackey, 1999) and pre-emptive focus on form (e.g., Ellis et al., 2001; Loewen, 2003). Ellis (2001) and Norris and Ortega (2000) argue that some type of form-focused instruction is beneficial for L2 learning. In a series of descriptive studies (Lyster and Ranta, 1997) described the different techniques that teachers used when reacting to student errors, suggesting that some types of feedback facilitate more student response than others. Oliver's (2000) study showed that ESL teachers provided a substantial amount of feedback in response to the students' non-target-like (NTL) production, regardless of the age of their learners, and that the learners made use of the feedback in their subsequent production.

Clearly type of corrective feedback used by teachers and the uptake shown by learners depends on different factors, for example context of the study, whether it is ESL or EFL, (Zhao, 2005). Sheen (2004) has compared teachers' feedback and learners' uptake in different EFL and ESL classrooms. Other researchers have investigated the relationship between learners' age and feedback types (e.g., Oliver, 2000; Mackey et al. 2003). Another important issue regarding corrective feedback is teachers' characteristics and beliefs that directly influence their choice of different types of feedback in their classes. One of these characteristics is teachers' level of experience.

\subsection{Teachers' experience in their use of focus-on-form techniques}

One individual difference that may play a major role in L2 teachers' use of incidental focus-on-form techniques is teachers' level of experience. Unlike focus on formS (synthetic approach of language teaching) and planned focus on form, both of which involve pre-planned activities directed toward specific language forms, incidental focus on form occurs spontaneously when teachers make on-line decisions about whether to interrupt their instructional routine in order to direct learners' attention to form. Research in L2 teacher education suggests that less experienced teachers are concerned with classroom management and maintaining the flow of instructional routines (Johnson, 1992; Numrich, 1996).

More experienced teachers may be more adept at implementing instructional routines, and may be more willing to deviate from their planned activities to provide incidental focus on form. However, an empirical study that examined the classroom discourse of L2 teachers with different levels of experience (Pica and Long, 1986) found no significant differences in the quantity of specific reactive focus-on form techniques used by experienced and inexperienced teachers. On the other hand, Mackey et al. (2004) suggest that teachers' use of incidental focus on form techniques is closely related with teachers' experience and education. They argue that experienced ESL teachers utilize more incidental focus on form techniques than novice teachers. 
The differences observed in the findings of studies addressing the role of teacher experience in use of incidental focus on form techniques highlight the need for more research in this area. In addition in these studies ESL classes have been investigated. So, the purpose of the current study is to address the association between teachers' experience and the type and frequency of incidental focus on form techniques they use in EFL classrooms in Iran. To meet this objective, the following research questions were made:

1. What types of incidental focus on form occur in EFL classrooms?

2. Do EFL teachers with contrasting levels of experience use different types and amounts of incidental focus on form?

\section{Method}

The main goal of the present study was to show the different ways in which a teacher could correct a student's oral error. This study aimed to provide information about whether there is a connection between the use of corrective feedback types and teachers' experience. This study involved a descriptive design which utilized both qualitative and quantitative data to address research questions.

\subsection{Context of the Study}

The research was conducted at a private school in Tabriz, Iran. The instructional approach of the school was within the communicative orientation of language teaching. Six intact classes with six different teachers participated in this study. The instructional approach of the school was within the communicative orientation of language teaching, with a strong emphasis on vocabulary development, speaking and listening activities, and, to a lesser degree, grammar, writing and reading. Thus, activities that focus on linguistic form were minimal, and the evaluation of the learners did not focus on accuracy of learner language. This means that the teachers had to rely on personal choices as to whether and when to focus on formal features of the language, including provision of corrective feedback.

\subsection{Participants}

In order to find out reasonable answers to research questions regarding the use of different types of incidental focus on form and teachers' experience, 88 students and 6 teachers participated in this study.

\subsubsection{Teachers}

Six teachers (female \& male) participated in this study. They had an experience of teaching EFL in different language schools for 2 or 12 years. All of the teachers were Iranian and their mother tongue was Azeri and they were fluent in Persian (the official language). The teachers' demographic information is provided in Table 2.

Table 2. Teachers' Demographic Information

\begin{tabular}{|l|l|l|l|l|l|}
\hline Class & Gender & Age & Teaching experience & EFL qualifications* & Time at school \\
\hline C1 & Female & 40 & 12 years & $\begin{array}{l}\text { MA in } \\
\text { TEFL/CELTA }\end{array}$ & 10 years \\
\hline C2 & female & 26 & 1 year & MA in TEFL & 3 years \\
\hline C3 & female & 32 & 9 years & MA in TEFL & 9 years \\
\hline C4 & male & 38 & 12 years & MA in TEFL & 10 years \\
\hline C5 & male & 26 & 2 years & BA & 1.5 years \\
\hline C6 & male & 30 & 3.5 years & BA & 2 years \\
\hline
\end{tabular}

MA: Master of Arts

BA: Bachelor of Arts

CELTA: Cambridge Certificate in English Language Teaching to Adults

Following the ethical guidelines at the work site, the researchers approached the six teachers and asked if they would be willing to participate in the study. The teachers were informed that the purpose of the research was to examine classroom interaction during meaning-focused lessons where there would be some focus on form; however, they would not be made aware of the precise focus of the study in order to minimize any effects 
relating to the observer's paradox. No effort was made to guide the teachers in their choice of lesson plans or selecting any type of corrective feedback. The teachers with different levels of experience were the participants in this research who were all non- native speakers of English and they used English as the medium of instruction.

They were divided into two groups as follows:

- Experienced teachers: teachers who had more than 8 years of teaching experience.

- Less-experienced teachers: those teachers who had less than 4 years of teaching experience.

\subsubsection{Learners}

The next group of participants was the intermediate level Iranian students at a private Language school in Iran. The EFL learners were female and at different ages (17-40). The number of students in each class ranged from 12 to 18, the total number of students was 88. They were fluent in Azeri (mother tongue) and Persian (official language). Students were seated in circles of chairs and teachers could walk in the middle of the classes. According to the students' application forms collected upon their registration, they were interested in learning English for a variety of reasons including academic purposes, professional development, TOEFL or IELTS tests, to brush up their English, and immigration to other foreign countries. The course books taught in these institutes are Interchange series (Richard et al., 2005).

\subsection{Data Collection Procedure}

The data were collected from the six EFL classes at intermediate levels with six teachers. The data comprised 9 hours (540 minutes) of audio and video-recorded classroom talk from the classrooms: 1 hour and 15 minutes for each class. Each class was equipped with a mini-video recorder placed in the top corners of the classrooms. This procedure provided data relating to any interaction involving the teachers and the whole class. The recordings of all the classes were conducted at the middle of the term so the learners had enough familiarity with course syllabus and the teacher's method.

\subsection{Coding System and Data Analysis Procedure}

The categories used to code the data in the present study were adopted from the error treatment sequence from those developed by Lyster and Ranta's (1997) model and Panova and Lyster (2002). The main unit of analysis was the error treatment sequence as: learner error and teacher feedback. All learners' utterances with errors were counted. After recording the classroom interactions, all corrective feedback types were identified, transcribed and coded according to Lyster and Ranta (1997) and Panova and Lyster (2002) models. Then frequencies and percentages of corrective feedback types were calculated for each teacher. Chi-square analysis was performed in order to test whether there was an association between the two variables, namely teachers' level of experience and corrective feedback types they used in their classes.

\section{Results and Discussion}

According to the Table 3, the teachers' most favorite type of feedback was recasts (56\%), the second most used feedback was elicitation $(11 \%)$ and the third was translation $(10 \%)$, and clarification request $(3 \%)$ was the least favourite type.

Table 3. Frequency of Corrective Feedback Types

\begin{tabular}{ll}
\hline \multicolumn{1}{c}{ Feedback types } & Number \\
\hline Recasts & $59(56 \%)$ \\
Elicitation & $12(11 \%)$ \\
Clarification request & $3(3 \%)$ \\
Explicit correction & $5(5 \%)$ \\
Repetition & $9(8 \%)$ \\
Metalinguistic feedback & $8(7 \%)$ \\
Translation & $10(10 \%)$ \\
\hline Total & $106(100 \%)$ \\
\hline
\end{tabular}




\section{International Journal of Applied Linguistics \& English Literature \\ ISSN 2200-3592 (Print), ISSN 2200-3452 (Online)}

Vol. 1 No. 6; November 2012

As it can be interpreted from Figure 1 and 2, experienced teachers used more incidental focus on form techniques $(64 \%)$ than novice teachers $(36 \%)$. The highest percentage belongs to recast, (experienced teachers: $30 \%$ and novice teachers: $28 \%$ ) and the lowest goes to explicit correction, (4\% and 1\%) respectively. Both groups used the same amount of translation type (5\%) and novice teachers did not apply any 'clarification request' and 'metalinguistic feedback' types in their classes.

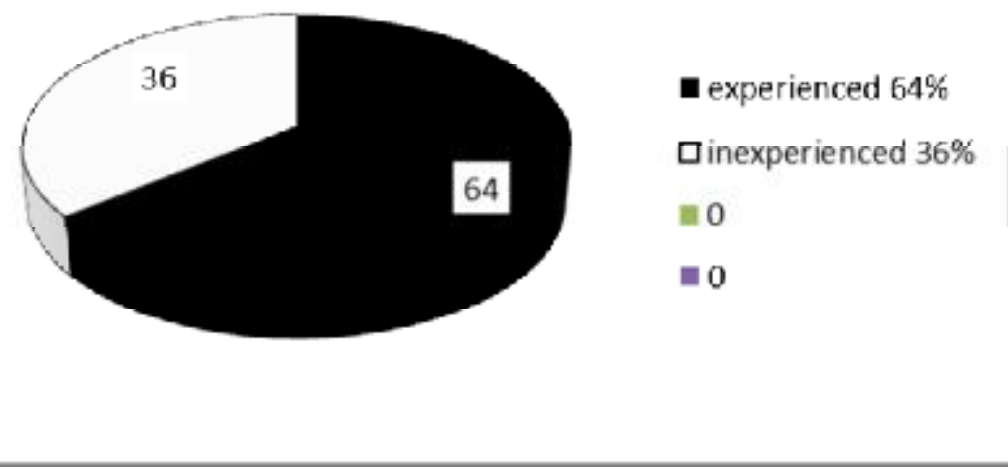

Figure 1. Corrective Feedback Types Distribution in Reference to Teachers Experiences

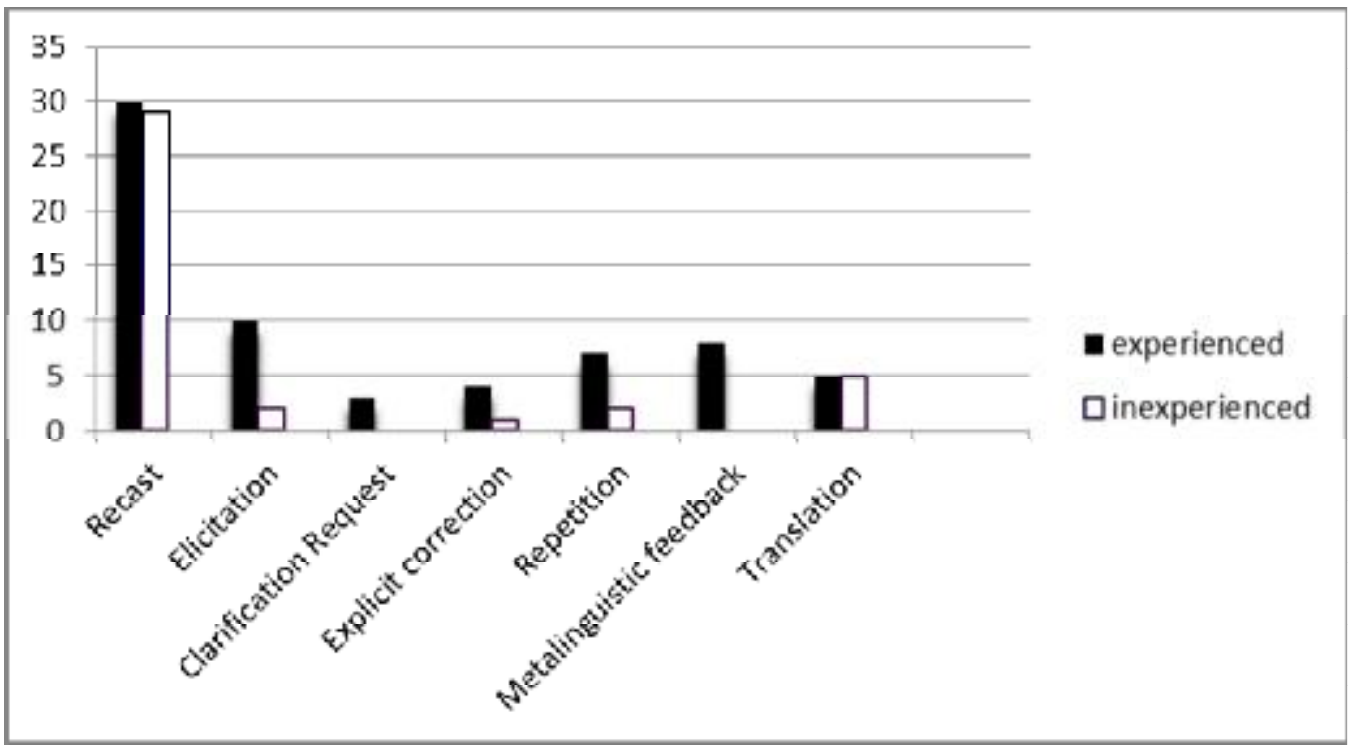

Figure 2. Percentage of Using Incidental Focus on Form Techniques by both groups (experienced/novice)

Table 4. Distribution of Corrective Feedback Types in all Classes

\begin{tabular}{|c|c|c|c|c|c|c|c|c|}
\hline & Recast & Elicitation & $\begin{array}{c}\text { Clarification } \\
\text { request }\end{array}$ & $\begin{array}{c}\text { Explicit } \\
\text { correction }\end{array}$ & Repetition & $\begin{array}{c}\text { Metalinguistic } \\
\text { feedback }\end{array}$ & Translation & Total \\
\hline Experienced & 30 & 10 & 3 & 4 & 7 & 8 & 5 & 67 \\
\hline Inexperienced & 29 & 2 & 0 & 1 & 2 & 0 & 5 & 39 \\
\hline Total & 59 & 12 & 3 & 5 & 9 & 8 & 10 & 106 \\
\hline
\end{tabular}

Teachers' experience and their use of Incidental focus on form

In order to find out whether there existed a statistically significant association between corrective feedback types and teachers' experience, the chi-square test was used. The result $\left(\mathrm{X}^{2}=145, d f=6, p<0.05\right)$ revealed that there is 
a statistically significant association. This suggests that experienced teachers are different from less-experienced teachers in terms of type and frequency of corrective feedback types they use in their classes.

The study of Lyster and Ranta (1997) revealed that while recasts were the most widely used corrective feedback, they were the least likely to lead to successful uptake. It was also found that the most successful type of feedback leading to students' repair was 'elicitation'. Based on their finding, it can be noticed that the novice teachers of this study did not use any 'elicitation' technique in their classes, so if it is true that certain types of incidental focus on form lead to more students uptake, teachers should be equipped with special training courses in order to increase the use of incidental focus on form types in their classes. As the table shows, experienced teachers were different from less-experienced teachers in terms of type and frequency of incidental focus on form types they used in their classes. With regard to the overall frequency of focus on form types, experienced teachers used more incidental focus on form comparing with inexperienced ones. So, this finding is in agreement with Mackey et al. (2004) who suggest that experienced teachers utilize more incidental focus on form techniques than novice teachers in ESL setting. But it should be noted that they investigated the ESL classrooms and this study is done in an EFL context.

\section{Conclusion}

In summary, experienced teachers were different from less-experienced teachers in terms of type and frequency of incidental focus on form types they used in their classes. The researchers found that experienced EFL teachers used incidental focus-on-form techniques more frequently than inexperienced teachers. Although inexperienced teachers did not implement some types of the focus-on form techniques in their classes (clarification request and metalinguistic feedback), it is assumed that their use of these techniques may change over time as their experience and familiarity with their classes increase. Since some focus on form techniques provide learners with more learning opportunities, they can help teacher training programs to equip teachers with knowledge of different types of focus on form techniques that they can implement in their classes.

The results of this study are valuable for EFL institutions and policy makers to reflect on the situation and improve their curricula and teacher training programs. EFL teacher educators can also use the data of the current study to design data-based tasks to foster reflection among prospective teachers. Borg (1998) recommends that teacher education programs take advantage of teachers' real practices and the rationale behind such practices to "provide an ideal platform for the kind of other-oriented inquiry which facilitates self-reflection" (p. 273). One advantage of designing data-based tasks could be their sensitivity to the context of EFL teaching where the practical concerns of the teaching situation are different from those of teaching English in a second language context. The authentic data provided here based on observations of real classes also reinforce "the links between research and teacher development, creating in teachers an awareness of the contribution which research in their own classrooms can make to their professional growth" (Borg, 1998, p. 281). These types of studies can bridge the gap that exists between theory, research and practice.

\section{References}

Askew, S. \& Lodge, C. (2000). Gifts, ping-pong and loops-linking feedback and learning. In Askew, S. (Ed.). Feedback for Learning (pp.1-17). London: Routledge.

Borg, S. (1998). Data-based teacher development. ELT Journal, 52(4), 273-281.

Brown, H. D. (2004). Principles of Language Learning and Teaching. Foreign Language Teaching and Research Press. Pearson Longman.

Ellis, R. (2001). Investigating form-focused instruction. Language Learning, 51, Supplement 1, 1-46.

Ellis, R., Basturkmen, H., \& Loewen, S. (2001a). Preemptive focus on form in the ESL classroom. TESOL Quarterly 35(3), 407-432. doi:10.2307/3588029, http://dx.doi.org/10.2307/3588029

Ellis, R., Basturkmen, H., \& Loewen, S. (2001b). “Learner uptake in communicative ESL lessons.” Language Learning, 51(2), 281-318. doi:10.1111/1467-9922.00156, http://dx.doi.org/10.1111/1467-9922.00156

Ellis, R., Basturkmen, H. \& Loewen, S. (2002). Doing focus-on-form. System, 30, 419-432.

doi:10.1016/S0346-251X(02)00047-7, http://dx.doi.org/10.1016/S0346-251X(02)00047-7

Ellis, R. (2009). Corrective feedback and teacher development. L2 Journal, Volume 1, 3-18.

Han, Z. (2002). A study of the impact of recasts on tense consistency in L2 output. TESOL Quarterly 36, 543-572. 
International Journal of Applied Linguistics \& English Literature

ISSN 2200-3592 (Print), ISSN 2200-3452 (Online)

Vol. 1 No. 6; November 2012

Johnson, K. (1992). Learning to teach: instructional actions and decisions of preservice ESL teachers. TESOL Quarterly 26: 507-34.

Krashen, S. (1982). Principles and practice in second language acquisition. Oxford: Pergamon.

Krashen, S. (1985). The Input Hypothesis: Issues and Implications. New York: Longman.

Leeman, J. (2003). Recasts and second language development: beyond negative evidence. Studies in Second Language Acquisition 25: 37-63.

Loewen, S. (2003). Variation in the frequency and characteristics of incidental focus on form. Language Teaching Research, 7, 315-345. doi:10.1191/13621688031r129oa, http://dx.doi.org/10.1191/13621688031r129oa

Long, M. H. (1991). Focus on form: A design feature in language teaching methodology. In K. De Bot, R. Ginsberg \& C. Kramsch (Eds.), Foreign Language Research in Cross-cultural Perspective. (pp.39-52). Amsterdam: John Benjamins.

Long, M. (1996). The role of the linguistic environment in second language acquisition. Handbook of Second Language Acquisition, ed. W. Ritchie \& T. Bhatia, 413-468. New York: Academic Press.

Long, M. \& Robinson, P. (1998). Focus on form: Theory, research and practice. Focus on Form in Classroom Second Language Acquisition, ed. C. Doughty \& J. Williams, 15-41. Cambridge: Cambridge University Press.

Long, M. (2000). Focus on form in task-based language teaching. In Lambert, R. and Shohamy, E., editors, Language policy and pedagogy, Philadelphia: John Benjamins, 179-92.

Lyster, R., \& Ranta, L. (1997). Corrective feedback and learner uptake: Negotiation of form in communicative classrooms. Studies in Second Language Acquisition, 19, 37-66.

Mackey, A. (1999). Input, interaction and second language development: an empirical study of question formation in ESL. Studies in Second Language Acquisition 21: 557-87.

Mackey, A. \& Philp, J. (1998). Conversational interaction and second language development: recasts, responses, and red herrings? The Modern Language Journal 82: 338-56.

Mackey, A., Oliver, R., \& Leeman, J. (2003). Interactional input and the incorporation of feedback: An exploration of NS-NNS and NNS-NNS adult and child dyads. Language Learning, 53, 35-66.

doi:10.1111/1467-9922.00210, http://dx.doi.org/10.1111/1467-9922.00210

Mackey, A., Polio, C. \& McDonough, K. (2004). The relationship between experience, education and teachers' Use of incidental focus-on-form techniques. Language Teaching Research, 8, 301-327.

Norris, J. and Ortega, L. (2000). Effectiveness of L2 instruction: a research synthesis and quantitative meta-analysis. Language Learning 50: 417-528.

Numrich, C. (1996). On becoming a language teacher: insights from diary studies. TESOL Quarterly 30: 131-53.

Oliver, R. (2000). Age differences in negotiation and feedback in classroom and pair work. Language Learning, 50, 119-151. doi:10.1111/0023-8333.00113, http://dx.doi.org/10.1111/0023-8333.00113

Panova, I., \& Lyster, R. (2002). Patterns of feedback and uptake in an adult ESL classroom. TESOL Quarterly, 36, 573-595.

Pica, T., \& Long, M. (1986). The linguistic and conversational performance of experienced and inexperienced teachers. In R. Day (Eds.), Talking to learn, (pp. 85-98). Rowley, MA: Newbury House.

Pica, T. (1994). Review article: Research on negotiation: what does it reveal about second-language learning conditions, processes, and outcomes? Language Learning 44: 493-527.

Schmidt, R. (1990). The role of consciousness in second language learning. Applied Linguistics, 11, $129-158$.

Schmidt, R. (2001): Attention. In Robinson, P., editor, Cognition and second language instruction. Cambridge: Cambridge University Press, 3-32.

Sheen, Y. H. (2004). Corrective feedback and learner uptake in communicative classrooms across instructional settings. Language Teaching Research, 8, 263-300. doi:10.1191/13621688041r146oa,

http://dx.doi.org/10.1191/1362168804lr146oa

Swain, M. (1998). Focus on form through conscious reflection. In C. Doughty \& J. Williams (Eds.), (Focus on form in classroom second language acquisition. (pp.64-81). Cambridge: Cambridge University Press.

Zhao, Y. (2005). Incidental focus on form in T-L interaction and L-L interaction. Unpublished doctoral dissertation. Auckland University of Technology, Auckland, New Zealand. 